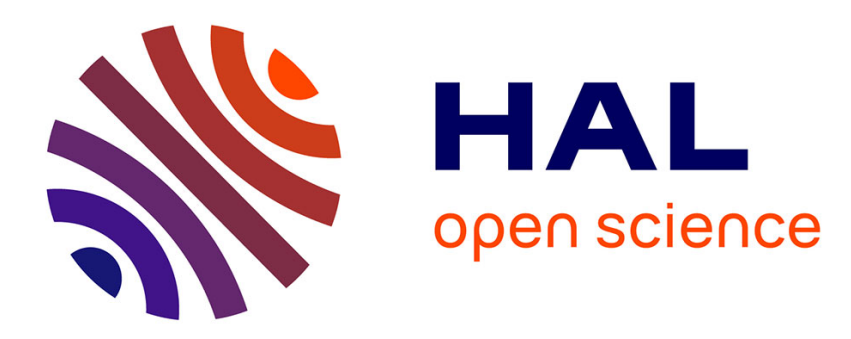

\title{
Stomatal conductance of some grapevines growing in the field under a Mediterranean environment
}

\author{
T. Winkel, S. Rambal
}

\section{To cite this version:}

T. Winkel, S. Rambal. Stomatal conductance of some grapevines growing in the field under a Mediterranean environment. Agricultural and Forest Meteorology, 1990, 51 (2), pp.107-121. 10.1016/01681923(90)90010-4 . ird-03373332

\section{HAL Id: ird-03373332 \\ https://hal.ird.fr/ird-03373332}

Submitted on 11 Oct 2021

HAL is a multi-disciplinary open access archive for the deposit and dissemination of scientific research documents, whether they are published or not. The documents may come from teaching and research institutions in France or abroad, or from public or private research centers.
L'archive ouverte pluridisciplinaire HAL, est destinée au dépôt et à la diffusion de documents scientifiques de niveau recherche, publiés ou non, émanant des établissements d'enseignement et de recherche français ou étrangers, des laboratoires publics ou privés. 


\title{
STOMATAL CONDUCTANCE OF SOME GRAPEVINES GROWING IN THE FIELD UNDER A MEDITERRANEAN ENVIRONMENT
}

\author{
T. WINKEL and S. RAMBAL \\ Centre National de la Recherche Scientifique, Centre Louis Emberger, BP 5051, F-34000 \\ Montpellier (France)
}

(Received November 25, 1988; revision accepted February 16, 1989)

\begin{abstract}
Winkel, T. and Rambal, S., 1990. Stomatal conductance of some grapevines growing in the field under a Mediterranean environment. Agric. For. Meteorol., 51: 107-121.

A semi-empirical model of stomatal conductance was used to analyse porometer measurements on different grapevine cultivars under field conditions. Stomatal conductance was expressed as a function of quantum flux density, water vapour deficit, air temperature and leaf water potential. Where possible, the parameters describing the partial functions were estimated from field data and provide physiological insights into the transpiration process. They indicated differential stomatal sensitivity to air humidity in the various cultivars, a characteristic which could be related to their geographical origins.
\end{abstract}

\section{INTRODUCTION}

The most generally successful model of evaporation from closed canopies is the well-known Penman-Monteith equation (Monteith, 1965). This model has been applied both to single leaves and to canopies. In the latter case, it has been chiefly used where fluxes might be expected to be predominantly onedimensional. In orchards or vineyards, horizontal heterogeneity requires a description in more than one dimension. For such row crops, the vegetation, by means of the stomata, plays a determining role in the control of bulk evaporation flux (Van Bavel et al., 1967; Hicks, 1973). Discontinuous canopies are aerodynamically rough and wind is only weakly attenuated (Riou et al., 1987) so that aerodynamic conductance of water vapour, which is proportional to eddy velocity and roughness length, is likely to be very high (Thom, 1975). In such cases, transpiration from the vegetation is strongly coupled with the air stream above the canopy and, because the transpiration rate is then closely proportional to the product of stomatal conductance and water vapour pres- 
sure deficit of the air, changes in stomatal conductance become of paramount importance (Thom, 1975; Jarvis and McNaughton, 1986).

Modelling mass transport and evaporation from this type of canopy should therefore involve the most likely realistic identification of the variables and laws governing stomatal functioning under field conditions. Among environmental factors that affect stomatal opening, solar radiation, soil water availability, atmospheric vapour pressure deficit and temperature are known to be important (Sheriff, 1979; Schulze, 1986; Turner, 1986a). Age, position in the canopy, internal $\mathrm{CO}_{2}$ concentration and hormonal equilibrium of the leaves, and previous growing conditions, also influence stomatal behaviour (Thomas et al., 1976; Blackman and Davies, 1985; Field, 1987). Whereas these intrinsic factors have been rarely investigated, several models have been proposed that relate stomatal aperture to simultaneous variations of weather factors, soil water deficit and plant water potential (Jarvis, 1976; Jones, 1983; Avissar et al., 1985).

When based on physical parameters, these models allow investigation of the regulation of water exchanges under natural conditions with relatively simple input data (Whitehead et al., 1981). Vegetation types can also be compared to improve understanding of the differential sensitivity to drought and generate hypotheses concerning the underlying mechanisms of water stress adaptation. In the case of cultivated vegetation, this knowledge will help to assess and compare the water requirements of various crops growing under given climatic conditions. In this paper, we examine the effects of weather variables and leaf water potential on the stomatal response of three grapevine cultivars grown in the field under Mediterranean climatic conditions.

\section{MATERIALS AND METHODS}

\section{Site description and data collection}

Field plots were located in the Aude valley, southern France $\left(43^{\circ} 13^{\prime} \mathrm{N}\right.$, $2^{\circ} 50^{\prime} \mathrm{E}$ ), at two sites $3.8 \mathrm{~km}$ apart with similar climatic conditions. The area has a Mediterranean-type climate with a potential evaporation rate of $\sim 1100$ $\mathrm{mm}$ year ${ }^{-1}$ and a mean annual rainfall (1961-1980) of $\sim 600 \mathrm{~mm}$, of which $<14 \%$ occurs during the summer (Canet, 1983). Different cultivars of grape were studied at the two sites, which differed in their soil type and soil water storage capacity. Available soil water has been used to indicate the difference between both sites; it was calculated from field capacity and minimum water storage, measured in 1986-1987 with a neutron moisture gauge. Soil was assumed to be at field capacity after a few days of drainage following a rainy period.

The first site consisted of two plots on a loamy soil in a flood plain, planted with grape cultivars carignane and merlot. Available soil water was $180 \mathrm{~mm}$ 
for the $0-130-\mathrm{cm}$ layer. The second site consisted of two plots on a stony terrace with a thick calcareous hard pan at 80-120-cm depth; plots were planted with carignane and shiraz vines. The available soil water, measured as described above, was only $120 \mathrm{~mm}$.

Vines were between 6 and 15 years old, and were therefore assumed to have fully developed root systems; soil water profiles showed root water uptake beyond $2-\mathrm{m}$ depth in the plots on the terrace. The carignane vines were goblet pruned, while merlot and shiraz were cordon trained.

A steady-state porometer (LI-1600, LI-COR Ltd., Lincoln, NE, U.S.A.) was used for simultaneous measurements of stomatal conductance, quantum flux density, water vapour deficit and air temperature (these latter two were measured within the porometer cup). These measurements were replicated six times. Concurrent measurements of leaf water potential, replicated three times, were obtained with a standard Scholander-type pressure chamber (PMS 1000, PMS Inst., Corvallis, OR, U.S.A. ). Data were collected on mature leaves in the sunny part of the canopy from dawn to $\sim 16: 00 \mathrm{~h}$ (LST) on 8 days spaced throughout most of the growth cycle (13 June, 27 June, 9 July and 15 August, 1986; 24 May, 2 June, 9 July and 11 September, 1987).

\section{Modelling procedure}

The method used was detailed by Jarvis (1976) and Jones (1983). The model was based upon known relationships between stomatal conductance $\left(g_{\mathrm{s}}, \mathrm{mmol}\right.$ $\left.\mathrm{m}^{-2} \mathrm{~s}^{-1}\right)$ and quantum flux density $\left(Q, \mu \mathrm{mol} \mathrm{m}^{-2} \mathrm{~s}^{-1}\right)$, water vapour pressure deficit $(D, \mathrm{kPa})$, air temperature $\left(T_{\mathrm{a}},{ }^{\circ} \mathrm{C}\right)$ and leaf water potential $(\psi, \mathrm{MPa})$. Its general form is

$g_{\mathrm{s}}=g_{\mathrm{sm}} \cdot g(Q) \cdot g(D) \cdot g\left(T_{\mathrm{a}}\right) \cdot g(\psi)$

where $g_{\mathrm{sm}}$ is maximum conductance of a given vine cultivar and each $g$ is the partial function for the indicated independent variable $(0 \leq g \leq 1)$ (Fig. 1).

The parameters that describe stomatal opening in response to the four independent variables were estimated from field measurements by non-linear least squares regression using Marquardt's method (Draper and Smith, 1966)

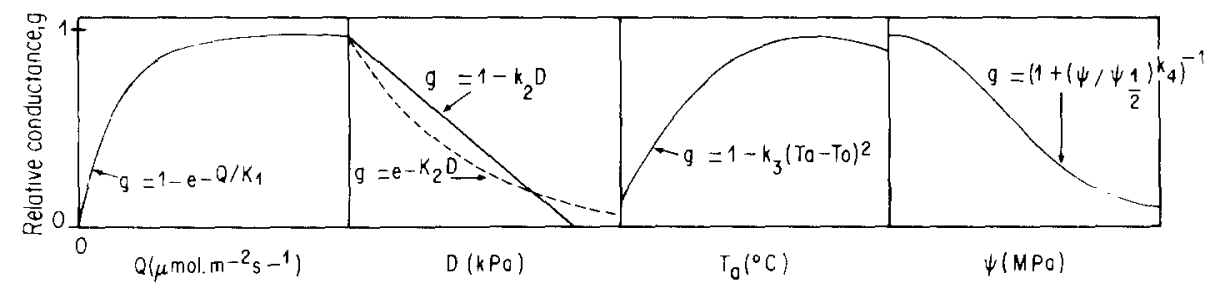

Fig. 1. Partial functions of the stomatal conductance response to quantum flux density $(Q)$, water vapour deficit $(D)$, air temperature $(T)$ and leaf water potential $(\psi)$ (redrawn after Jones, 1983). 
or trial and error estimations. This approach enabled us to take into account the functional relationships controlling stomatal behaviour and to interpret parameters in a physical sense (Reed et al., 1976). As stated by Jarvis (1976), such a model is not mechanistic because it does not link environmental factors with stomatal functioning at the cellular level. Nevertheless, its semi-empirical character makes it useful for the interpretation of field observations and prediction of stomatal conductance, even for environmental conditions not directly tested.

Two limitations of this approach must be outlined. First, probable interactions between variables are ignored. Response functions given in the literature were obtained in controlled environments in which only one or two factors were varied at a time. In reality, all the factors act simultaneously in interconnected processes and interactions are expected. However, to our knowledge, such complex combinations between factors have not yet been formalized. Secondly, the data sets collected in the field usually show strong correlations between variables, resulting in possible bias in estimation of the parameters (Jarvis, 1976). The narrow range of certain variables could also be a handicap.

\section{Variables and partial functions}

\section{Solar radiation}

The stomatal response to sunlight is influenced by several internal factors, including leaf age and plant water status (Squire and Black, 1981; Field, 1987). This leads to quite variable relationships between conductance and sunlight (Cowan, 1977). However for well-watered plants it is usually considered that stomatal conductance shows a hyperbolic response to sunlight. This relationship can be described by the equation

$g(Q)=1-\exp \left(-Q / K_{1}\right)$

where $Q$ stands for the quantum flux density or photosynthetically active radiation. The parameter, $K_{1}$, is derived from the minimum $Q$ value required for a nearly maximum stomatal aperture. For a number of species, this $Q$ value is $\sim 400 \mu \mathrm{mol} \mathrm{m}^{-2} \mathrm{~s}^{-1}$ (Squire and Black, 1981; Jones, 1983), in accord with the values of $200 \mathrm{~W} \mathrm{~m}^{-2}$ of global radiation given by Kriedemann and Smart (1971) and of $300 \mu \mathrm{mol} \mathrm{m}^{-2} \mathrm{~s}^{-1}$ found by Liu et al. (1978) for grapevine cultivars. Assuming 95\% relative stomatal conductance at a quantum flux density of 400 $\mu \mathrm{mol} \mathrm{m} \mathrm{m}^{-2} \mathrm{~s}^{-1}$, we calculate a $K_{1}$ value of $133 \mu \mathrm{mol} \mathrm{m}^{-2} \mathrm{~s}^{-1}$. This value is applied for all the studied grapevine cultivars, making the hypothesis that light acts on stomatal aperture by stimulating metabolic processes at the cellular level, which are independent of varietal type. 


\section{Water vapour pressure deficit}

Many species close their stomata in response to increased water vapour pressure deficit (Sheriff, 1979; Schulze, 1986). The stomatal response to humidity could be linear or curvilinear depending on the control system involved; a direct feedforward response results in a linear relationship (Camacho-B et al., 1974; Farquhar et al., 1980), whereas a feedback response via leaf water status leads to a non-linear relationship (Johnson and Ferrel, 1983). We compared both types of relationships

$\begin{array}{ll}g(D)=1-K_{2} \cdot D & \text { if } D<1 / K_{2} \\ g(D)=0 & \text { if } D \geq 1 / K_{2}\end{array}$

and

$g(D)=\exp \left(-K_{2} \cdot D\right)$

where $D$ is the vapour pressure deficit of the air near the leaf and $K_{2}$ is a parameter estimated from the data set.

\section{Air temperature}

The effect of air temperature on stomatal conductance is difficult to separate from that of humidity because vapour pressure deficit and air temperature are correlated. However it is widely accepted (Stälfelt, 1962) that stomatal conductance reaches a maximum at $30-35^{\circ} \mathrm{C}$. Such a response curve may be written (Jones, 1983)

$$
\begin{array}{ll}
g(T)=1-K_{3} \cdot\left(T_{\mathrm{a}}-T_{\mathrm{o}}\right)^{2} & \text { if }\left(T_{\mathrm{a}}-T_{\mathrm{o}}\right)^{2}<1 / K_{3} \\
g(T)=0 & \text { if }\left(T_{\mathrm{a}}-T_{\mathrm{o}}\right)^{2} \geq 1 / K_{3}
\end{array}
$$

where $T_{\mathrm{a}}$ is the air temperature near the leaf and $T_{\mathrm{o}}$ is the optimum temperature for stomatal opening $\left(g\left(T_{\mathrm{o}}\right)=1\right) ; T_{\mathrm{o}}$ and $K_{3}$ were estimated from the field measurements.

\section{Leaf water potential}

Although bulk leaf water potential is the biological variable most often considered in studies of stomatal function, it is not considered to directly control plant water loss. Instead, turgor pressure in guard cells and hormonal regulators are reported to play the dominant roles (Zeiger, 1983; Schulze, 1986). Moreover, Turner (1986b) pointed out how different rates of soil drying and air vapour deficit could induce a lack of correlation between leaf conductance and leaf water potential. Nevertheless, partly because of ease of measurement in the field, leaf water potential remains a widely used state variable for functional rather than mechanistic models such as we are seeking. The response of conductance to leaf water potential can be modelled with a two-parameter relationship (Rambal, 1980; Jones, 1983; Campbell, 1985) 
$g(\psi)=1 /\left(1+\left(\psi / \psi_{\frac{1}{2}}\right)^{K_{4}}\right)$

where $\psi_{1}$ is the critical leaf water potential (i.e. the value required to reduce maximum conductance by half) and $K_{4}$ is an empirically derived parameter that describes the rate of decrease of $g_{s}$ with $\psi$.

\section{APPLICATION OF THE MODEL}

\section{Determination of parameters}

The model requires seven parameters; $g_{\mathrm{sm}}, K_{1}, K_{2}, T_{\mathrm{o}}, K_{3}, \psi_{\frac{1}{2}}$ and $K_{4}$. For each vine plot, field measurements of each independent variable were randomly assigned to one of two data sets, one for estimation of the parameters (Table 1) and the other for validation of the model.

Maximum stomatal conductance of each of the three cultivars was directly estimated from the field measurements by taking the highest value observed in 1986-1987 (mean of six replicated measurements). Assuming this parameter to be only under genotypic dependence, the same value was adopted for carignane on both sites. Statistical differences appear between the carignane and shiraz cultivars $(P=0.01)$, while merlot, with an intermediate value, differs from the other two only at the $10 \%$ probability level. Values were similar

TABLE 1

Parameter values of the model derived from the first data set $\left({ }^{\mathrm{L}}\right.$ and ${ }^{\mathrm{E}}$ refer to linear and exponential humidity responses, respectively, $r^{2}$ is the coefficient of determination, $n$ is the number of observations

\begin{tabular}{|c|c|c|c|c|c|c|c|c|}
\hline & \multicolumn{4}{|c|}{ Flood plain } & \multicolumn{4}{|c|}{ Terrace } \\
\hline & \multicolumn{2}{|c|}{ Merlot } & \multicolumn{2}{|c|}{ Carignane } & \multicolumn{2}{|c|}{ Carignane } & \multicolumn{2}{|c|}{ Shiraz } \\
\hline$g_{\mathrm{sm}}\left(\mathrm{mmol} \mathrm{m}{ }^{-2} \mathrm{~s}^{-1}\right)$ & \multicolumn{2}{|c|}{$\begin{array}{l}440 \\
(41)\end{array}$} & \multicolumn{2}{|c|}{$\begin{array}{l}560 \\
(41)\end{array}$} & \multicolumn{2}{|c|}{$\begin{array}{l}560 \\
(41)\end{array}$} & \multicolumn{2}{|c|}{$\begin{array}{c}360 \\
(14)\end{array}$} \\
\hline $\begin{array}{l}K_{1}\left(\mu \mathrm{mol} \mathrm{m}^{-2} \mathrm{~s}^{-1}\right) \\
T_{\mathrm{o}}\left({ }^{\circ} \mathrm{C}\right) \\
K_{4}\end{array}$ & & & & \multicolumn{4}{|c|}{$\begin{array}{r}30 \\
2\end{array}$} & \\
\hline$\psi_{\frac{1}{2}}(\mathrm{MPa})$ & \multicolumn{2}{|c|}{1.6} & \multicolumn{2}{|c|}{1.4} & \multicolumn{2}{|c|}{1.4} & \multicolumn{2}{|c|}{1.8} \\
\hline$K_{2}^{2}\left(\mathrm{kPa}^{-1} \times 10^{-3}\right)$ & $\begin{array}{r}88^{\mathrm{L}} \\
(13)\end{array}$ & $\begin{array}{l}114^{\mathrm{E}} \\
(18)\end{array}$ & $\begin{array}{r}95^{\mathrm{L}} \\
(13)\end{array}$ & $\begin{array}{l}116^{\mathrm{E}} \\
(18)\end{array}$ & $\begin{array}{r}96^{\mathrm{L}} \\
(12)\end{array}$ & $\begin{array}{l}125^{\mathrm{E}} \\
(17)\end{array}$ & $\begin{array}{r}24^{\mathrm{L}} \\
(12)\end{array}$ & $\begin{array}{r}26^{\mathrm{E}} \\
(14)\end{array}$ \\
\hline$K_{3}\left({ }^{c} \mathrm{C}^{-2} \times 10^{-4}\right)$ & $\begin{array}{l}46^{\mathrm{L}} \\
(4)\end{array}$ & $\begin{array}{l}45^{\mathrm{E}} \\
(4)\end{array}$ & $\begin{array}{l}51^{\mathrm{L}} \\
(4)\end{array}$ & $\begin{array}{l}50^{\mathrm{E}} \\
(4)\end{array}$ & $\begin{array}{l}47^{\mathrm{L}} \\
(4)\end{array}$ & $\begin{array}{r}50^{\mathrm{E}} \\
(4)\end{array}$ & $\begin{array}{l}40^{\mathrm{L}} \\
(4)\end{array}$ & $\begin{array}{l}40^{E} \\
(4)\end{array}$ \\
\hline $\begin{array}{l}r^{2}(\%) \\
n=114\end{array}$ & $80^{\mathrm{L}}$ & $82^{\mathrm{E}}$ & $85^{\mathrm{L}}$ & $85^{\mathrm{E}}$ & $83^{\mathrm{L}}$ & $84^{\mathrm{E}}$ & $88^{L}$ & $88^{\mathrm{E}}$ \\
\hline
\end{tabular}

Numbers in parentheses show the standard error of the mean. 
to those given in the literature for field-grown cultivars (Körner et al., 1979; Katerji and Daudet, 1986).

The parameter $K_{1}$, which describes the stomatal response to quantum flux density, was set at a value of $133 \mu \mathrm{mol} \mathrm{m}^{-2} \mathrm{~s}^{-1}$ for the four plots, as previously explained.

Estimation of the other parameters from field observations was less straightforward. Plots of $g_{\mathrm{s}}$ against each independent variable generally show considerable scatter and the upper boundary of points - theoretically representative of the stomatal response to one variable when the others are not limiting usually appears discontinuous and irregular (Jarvis, 1976). In addition, the functional relationship between $g_{s}$ and each driving variable was difficult to fully characterize, partly because the range of variables was restricted (Table 2 ). These field measurements however are representative of the "non-ideal data of the kind frequently gathered" (Reed et al., 1976). In view of these difficulties, we initialized the model by setting the values of the parameters $T_{\mathrm{o}}$, $\psi_{\frac{1}{3}}$ and $K_{4}$. This was done by trial and error, keeping values realistic with respect to the limits of leaf functioning and leading to a percentage of explained variance as high as possible. $K_{2}$ and $K_{3}$ were obtained by non-linear regression.

From our field measurements, a temperature of $30^{\circ} \mathrm{C}$ was found to be optimal for the stomatal conductance of the three cultivars and $K_{4}$ was set to 2 , representing the progressive decrease of $g_{s}$ with a decrease in leaf water potential. The estimates of $\psi_{\frac{1}{2}}$ adopted to run the model were $-1.4 \mathrm{MPa}$ for carignane, $-1.6 \mathrm{MPa}$ for merlot and $-1.8 \mathrm{MPa}$ for shiraz. These values correspond fairly well with those derived by stratifying the data and using a boundary-line analysis (Webb, 1972) (Fig. 2). The estimated values of $K_{2}$ and $K_{3}$ for different cultivars showed a positive correlation, reflecting the interdependence between air temperature and humidity. They revealed significant differences between vine cultivars, especially regarding their reaction to water vapour deficit. As for $K_{3}$, its estimates may be relevant only to the range of observed air temperature as they imply complete stomatal closure at $\sim 15^{\circ} \mathrm{C}$, which seems an unrealistic value.

TABLE 2

Range of environmental variables used for estimation of the parameters

\begin{tabular}{lcrrrr}
\hline & \multicolumn{2}{l}{ Flood plain } & & & \multicolumn{2}{l}{ Terrace } & \\
\cline { 2 - 3 } & \multicolumn{1}{l}{ Merlot } & Carignane & & Carignane & \multicolumn{1}{c}{ Shiraz } \\
\hline$Q\left(\mu \mathrm{mol} \mathrm{m}{ }^{-2} \mathrm{~s}^{-1}\right)$ & $7-2080$ & $27-2060$ & & $34-2050$ & $6-2140$ \\
$T_{\mathrm{a}}\left({ }^{\circ} \mathrm{C}\right)$ & $15.6-38.4$ & $15.6-37.6$ & & $17.2-38.0$ & $16-38.6$ \\
$D(\mathrm{kPa})$ & $0.42-4.27$ & $0.44-4.45$ & & $0.72-5.0$ & $0.48-5.22$ \\
$\psi(\mathrm{MPa})$ & $0.25-1.57$ & $0.28-1.40$ & & $0.32-1.53$ & $0.45-1.63$
\end{tabular}




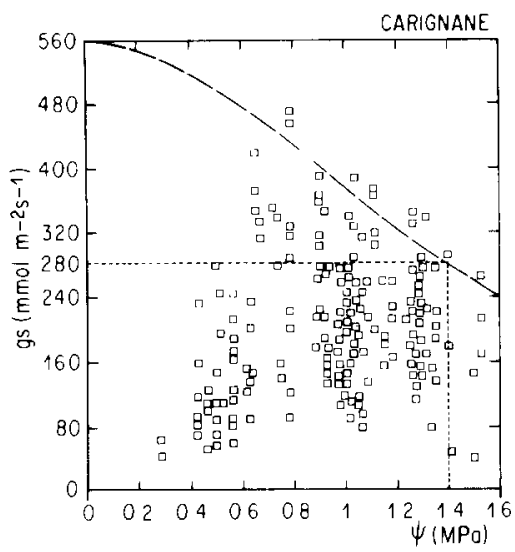

Fig. 2. Scatter diagram of stomatal conductance $\left(g_{\mathrm{B}}\right)$ against leaf water potential $(\psi)$ measured on the two carignane plots, with the curve derived from eq. 5 with $\psi_{1}=-1.4 \mathrm{MPa}$ and $K_{4}=2$.
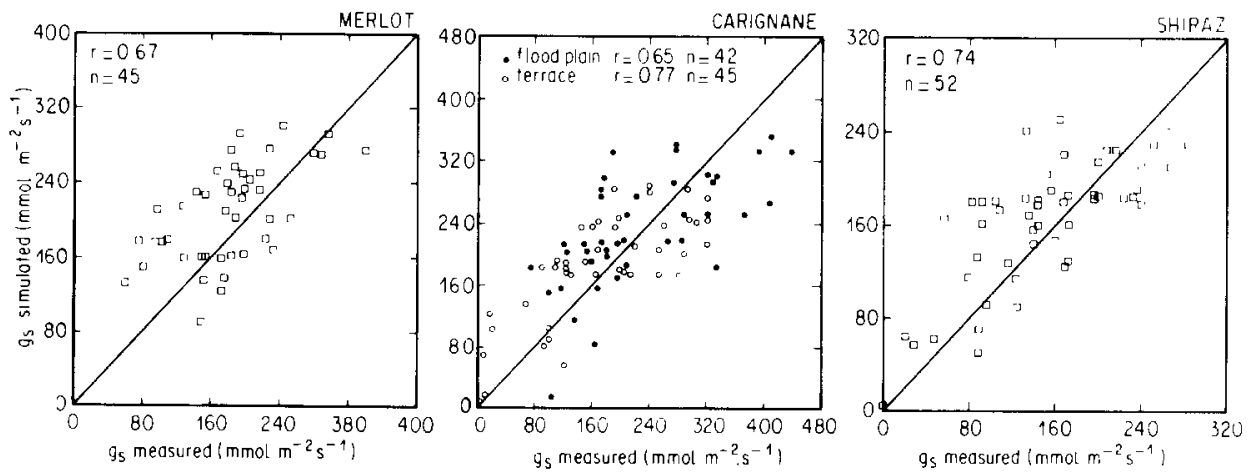

Fig. 3. Relationship between measured and simulated values of stomatal conductance ( $r$ is the coefficient of correlation, $n$ is the number of points).

The model accounts for $80-88 \%$ of the variation in the four data sets (Table 1). Because the alternative assumptions of the linear and exponential response of conductance to air humidity explained similar proportions of variation, we adopted the simpler one (eq. 3 ).

\section{Validation of the model}

The model was tested by comparing the observations of the second data set with the stomatal conductances estimated from the input variables of this set, with the parameters derived from the first set of measurements. Although Fig. 3 shows a large spread of points, simulated and measured values did not differ significantly, except in the case of merlot (Table 3 ). Likewise, diurnal varia- 


\section{TABLE 3}

Comparison of stomatal conductances observed and simulated for the four experimental plots $(r$ is the coefficient of correlation, $n$ is the number of observations )

\begin{tabular}{lccccc}
\hline & Flood plain & & & \multicolumn{2}{c}{ Terrace } \\
\cline { 2 - 3 } \cline { 5 - 6 } & Merlot & Carignane & & Carignane & Shiraz \\
\hline Mean residual & $-0.07^{*}$ & $-0.01^{\text {ns }}$ & & $-0.03^{\text {ns }}$ & $-0.03^{\text {ns }}$ \\
$r$ & 0.67 & 0.65 & & 0.77 & 0.74 \\
$n$ & 45 & 42 & 45 & 52 \\
\hline
\end{tabular}

${ }^{\mathrm{ns}}$ not significant.

* significantly different at $P=0.05$.
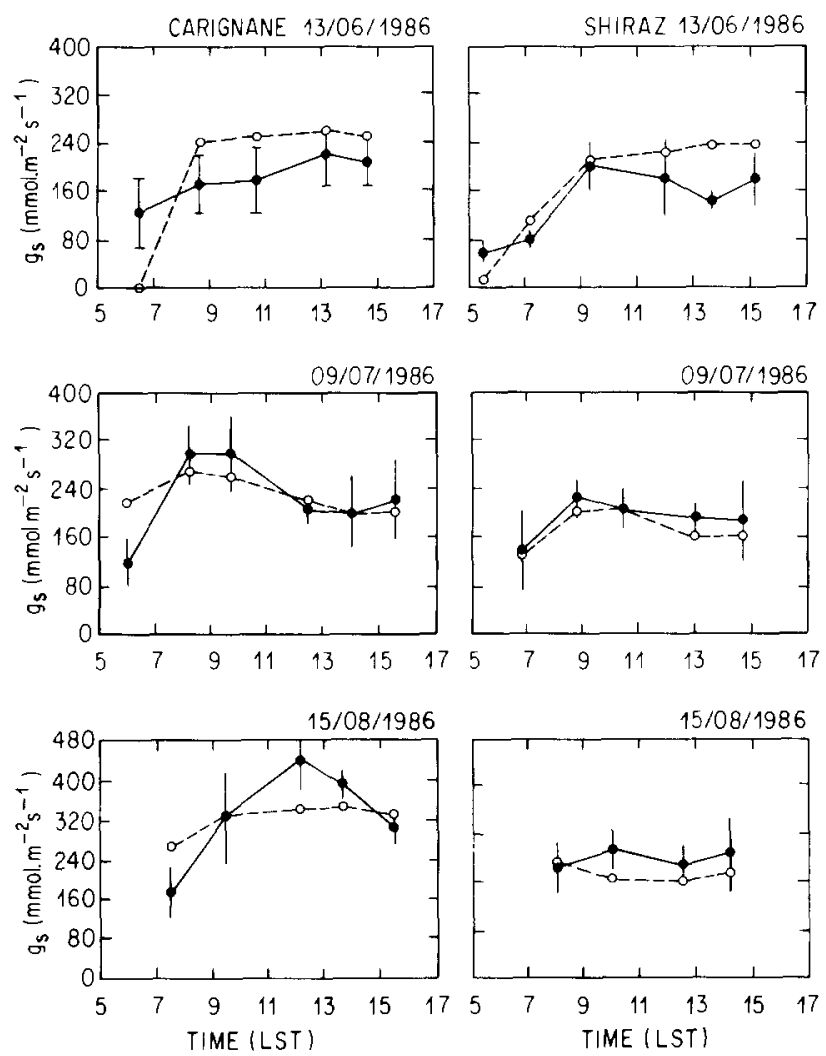

Fig. 4. Diurnal variations of observed (solid line) and simulated (dotted line) stomatal conductance (the vertical bars show the standard deviation of the observed values).

tions of simulated conductances were similar to those measured in the field, the model being particularly able to represent the closure of the stomata at midday (Fig. 4). 
The most noticeable divergence between predicted and observed values occurred early in the day, when rapid changes in light level and wind speed may outpace the capacity for stomatal response (Williams, 1983). Systematic differences also occurred on certain dates. Estimated conductance was relatively accurate in the four plots on 9 July, but was generally underestimated on 15 August and overestimated on 13 June. This may represent the effect of season on plant development. In particular, the maximum stomatal conductance is known to increase during the development cycle of the plant (Jones, 1983; Chaves and Rodrigues, 1987) and the adoption of a constant value for $g_{s m}$ would therefore tend to overestimate conductance at the beginning of the vegetation period, when the leaves are not yet fully expanded. Underestimation of conductance in mid-season (15 August) is less easy to explain, but may have been linked to the growth history. Pre-conditioning by repeated soil water depletion can lead to a progressive decrease in the threshold leaf water potential for stomatal closure (Thomas et al., 1976; Ackerson, 1980). For the grapevine, although they did not concern studies with repeated water stress cycles, the results of Düring and Loveys (1982) and Chaves and Rodrigues (1987) gave an explanation for this phenomenon. They showed that in stressed vines (i.e. with low bulk water potential) the turgor pressure necessary for the stomatal aperture is maintained by a decrease in osmotic potential. This decrease results from an active accumulation of solutes in the leaf tissues when water stress develops.

\section{DISCUSSION}

Our results, with data from the literature, permit some hypotheses to be put forward on the mechanisms that regulate water transport at the leaf level. The similarity of parameters estimated for the two different plots of carignane, and the divergence between cultivars, suggest that genetic differences in stomatal response to the environment were more important than site differences.

A degree of differentiation among cultivars was first apparent in values of $g_{s m}$; maximum stomatal conductances of the merlot and shiraz cultivars were respectively, 20 and $35 \%$ below that of carignane, the difference being significant between carignane and shiraz only $(P=0.01)$. Although a genetic component seems likely to be involved, this would need to be confirmed by a systematic comparison of grapevine cultivars. Moreover, the maximum stomatal conductance of shiraz was likely to have been limited by previous conditions of cultivation, particularly lack of irrigation since planting time, which would have been a harsh constraint for this cultivar, known for its drought sensitivity. Analysis of stomatal responses to vapour pressure deficit and leaf water potential provides some insight into the development of drought resistance by grapevines.

The low rate at which the stomata react to a decrease in leaf water potential 
(parameter $K_{4}$ ) is typical of plants grown in the field, where soil water depletion usually occurs gradually and allows plants to respond by osmotic adjustment or control via phytohormones, and continuous root growth (Turner, 1986a; Rambal, 1988). Osmotic adjustment in particular has been demonstrated for grapevines growing under semi-arid conditions (Düring and Loveys, 1982).

This process provides an explanation for the decrease in the critical potential for stomatal closure in plants subjected to progressive water stress. It also explains the differences between field and controlled environment studies. In our experiment, $\psi_{1}$ reached a value of $-1.8 \mathrm{MPa}$ for shiraz, whereas Kriedemann and Smart (1971) found a critical potential of -1.3 MPa for the same cultivar grown in containers without irrigation. The lower critical potential of shiraz, as compared with merlot or carignane, could be linked to vegetative characteristics. Ludlow (1980) stated that plants exhibiting stomatal adjustment cannot survive without some tolerance to dehydration, since stomata that adjust osmotically remain partially open and water loss continues. He also added that this tolerance to dehydration is usually associated with slow rates of growth and development. On the other hand, Turner (1986b) outlined the advantage presented by this type of functioning in the maintenance of water uptake; it allows continued root growth at low water potential and enables the plant to explore a greater volume of soil. We observed both features in shiraz; its rooting depth exceeded $2 \mathrm{~m}$ and its vegetative development appeared significantly reduced compared with the neighbouring carignane plants ( 450 and $590 \mathrm{~g}$, respectively, of dry mass of shoot per plant in 1987).

Plants that cannot endure dehydration avoid low water potential by sensitive control of water loss from the leaves. Direct stomatal response to air humidity plays a determining role here. Evidence for this response in grapevines is contradictory, particularly regarding the sensitivity of unstressed plants (Düring, 1976, 1987; Lange and Meyer, 1979; Kliewer et al., 1983). Considering the processes underlying this humidity sensing, the distinction between feedforward (eq. 3) and feedback (eq. 3a) control is of importance as it involves quite different behaviours regarding economy in use of water. Cowan (1977) demonstrated theoretically how a feedforward response confers a distinct advantage in dry environments. Our data do not allow us to distinguish between the two possibilities, although they clearly indicate a differential sensitivity to air vapour deficit for vine cultivars grown in the field.

The more pronounced humidity response of the carignane and merlot vines, which also show the higher threshold potentials, is in accord with Ludlow's statement that humidity response is of special importance for plants lacking tolerance to dehydration (Ludlow, 1980). Via this mechanism, transpiration loss is restricted when atmospheric demand becomes too high, helping to increase the daily water use efficiency. The very high productivity of these two cultivars (Winkler et al., 1974) supports this contention. Loveys and Kriede- 
mann (1973) and then Düring (1976) found greater stomatal responses to humidity in stressed vines; while Schulze and Küppers (1979) found that longterm stress did not alter the slope of the conductance/humidity relationship, but rather decreased the range of stomatal response. In our study, one or other of these processes should have induced differences among the two carignane vines according to their contrasting soil water resources. This was not observed, which suggests stress avoidance by the carignane grown on the terrace, probably by means of its deep root system.

Further, the similarity of $K_{2}$ for the two different plots of carignane suggests that this parameter is a species characteristic. Kriedemann (1978) points out that even though inference of genetic influences from physiological observations is highly tentative, geographic origins of grapevine taxa can provide useful information about their physiological characteristics. This also seems to be true for grapevine cultivars traditionally linked to a given region, in which physiological characters may have been influenced by their evolution in specific environments (Rives, 1975). The carignane, merlot and shiraz cultivars we studied originated, respectively, from Spain (Aragon), the Bordeaux region and the Rhône valley. Aragon has a strong semi-arid climate (Font Tullat, 1983), while the other two regions show summer rain deficits partly limited by periods of mist (Rey, 1957). The contrasting responses of carignane and shiraz $(P=0.01)$ therefore appear consistent with their geographical origin; carignane, well known for its hardiness, could have adapted to climatic drought by developing sensitivity to air vapour deficit, a capacity that shiraz, native to a more mesic region, would not have developed to the same extent. While the contrast between carignane and shiraz could be analysed through their stomatal reaction to only one environmental factor (viz. air humidity), understanding the intermediate position of merlot (high stomatal sensitivity, mesic origin) needs to consider the plant as a whole. Plant response to water stress involves, besides regulation at the stomatal level, several mechanisms acting at larger time scales (Rambal, 1988); hydraulic resistance to water flow between roots and leaves, and root/shoot ratio, could also provide an explanation for the differences in water relations between cultivars.

\section{ACKNOWLEDGEMENTS}

We are most grateful to $\mathrm{M}$. Grandjanny and M. Maistre for help with the field work. Special thanks are extended to J.C. Jacquinet and his staff of agricultural advisers of the Chambre d'Agriculture de l'Aude. We also thank V. Ghersi-Egea and P. Alpert for improving the quality of the text. This study was conducted with the support of the Programme Interdisciplinaire de Recherches sur l'Environnement (PIREN) of the C.N.R.S. (Grants Nos. 8682$613,8760-5069$ and 8860-5053). 


\section{REFERENCES}

Ackerson, R.C., 1980. Stomatal response of cotton to water stress and abscissic acid as affected by water stress history. Plant Physiol., 65: 455-459.

Avissar, R., Avissar, P., Mahrer, Y. and Bravdo, B.A., 1985. A model to simulate response of plant stomata to environmental conditions. Agric. For. Meteorol., 34: 21-29.

Blackman, P.G. and Davies, W.J., 1985. Cytokinins, abscissic acid and the control of plant water balance. Acta Hortic., 171: 255-262.

Camacho-B, S.E., Hall, A.E. and Kaufmann, M.R., 1974. Efficiency and regulation of water transport in some woody and herbaceous species. Plant Physiol., 54: 169-172.

Campbell, G.S., 1985. Soil Physics with Basic. Transport Models for Soil-Plant Systems. Elsevier, Amsterdam, $150 \mathrm{pp}$.

Canet, I., 1983. Eléments climatologiques du Languedoc-Roussillon. Ec. Nat. Météorol., Note No. 34,154 pp. + maps.

Chaves, M.M. and Rodrigues, M.L., 1987. Photosynthesis and water relations of grapevines growing in Portugal. Response to environmental factors. In: J.D. Tenhunen, F.M. Catarino, O.L. Lange and W.C. Oechel (Editors), Plant Response to Stress. Functional Analysis in Mediterranean Ecosystems. NATO ASI Ser. G, 15: 379-390.

Cowan, I.R., 1977. Stomatal behaviour and environment. Adv. Bot. Res., 5: 117-227.

Draper, N.R. and Smith, H., 1966. Applied Regression Analysis. Wiley, New York/London/Sidney, $407 \mathrm{pp}$.

Düring, H., 1976. Untersuchungen zur Umweltabhängigkeit der stomatären Transpiration bei Reben. I. Beleuchtungstärke und Luftfeuchtigkeit. Vitis, 15: 82-87.

Düring, H., 1987. Stomatal responses to alterations of soil and air humidity in grapevines. Vitis, 26: $9-18$.

Düring, H. and Loveys, B.R., 1982. Diurnal changes in water relations and abscissic acid in field grown Vitis vinifera cultivars. I. Leaf water potential components and leaf conductance under humid temperate and semiarid conditions. Vitis, 21: 223-232.

Farquhar, G.D., Schulze, E.D. and Küppers, M., 1980. Responses to humidity by stomata of $\mathrm{Ni}$ cotiana glauca L. and Corylus avellana L. are consistent with the optimisation of carbon dioxide uptake with respect to water loss. Aust. J. Plant Physiol., 7: 315 -327.

Field, C.B., 1987. Leaf-age effects on stomatal conductance. In: E. Zeiger, G.D. Farquhar and I.R. Cowan (Editors), Stomatal Function. Stanford University Press, Stanford, CA, pp. 367-384.

Font Tullat, I., 1983. Climatologìa de España y Portugal. Inst. Nac. Met., Madrid, 296 pp.

Hicks, B.B., 1973. Eddy fluxes over a vineyard. Agric. Meteorol., 12: 203-215.

Jarvis, P.G., 1976. The interpretation of the variations in leaf water potential and stomatal conductance found in canopies in the field. Phil. Trans. R. Soc. London Ser. B, 273: 593-610.

Jarvis, P.G. and McNaughton, K.G., 1986. Stomatal control of transpiration: scaling up from leaf to region. Adv. Ecol. Res., 15: 1-49.

Johnson, J.D. and Ferrell, W.K., 1983. Stomatal response to vapour pressure deficit and the effect of plant water stress. Plant Cell Environ., 6: 451-456.

Jones, H.J., 1983. Plants and microclimate. A quantitative approach to environmental plant physiology. Cambridge University Press, Cambridge, $323 \mathrm{pp}$.

Katerji, N. and Daudet, F.A., 1986. Etude in situ du fonctionnement hydrique et photosynthétique d'une vigne conduite en lyre. Agronomie, 6: 709-716.

Kliewer, W.M., Freeman, B.M. and Hoosom, C., 1983. Effect of irrigation, crop level and potassium fertilization on Carignane vines. I. Degree of water stress and effect on growth and yield. Am. J. Enol. Vitic., 34: 186-196.

Körner, C.. Scheel, J.A. and Bauer, H., 1979. Maximum leaf diffusive conductance in vascular plants. Photosynthetica, 13: 45-82.

Kriedemann, P.E., 1978. Vineleaf photosynthesis. In: Oenological and Viticultural Research In- 
stitute (Editor), Quality of the Vintage. Proc. Int. Symp. OIV, 14-21 February 1977, Cape Town, pp. 67-87.

Kriedemann, P.E. and Smart, R.E., 1971. Effects of irradiance, temperature and leaf water potential on photosynthesis of vine leaves. Photosynthetica, 5: 6-15.

Lange, O.L. and Meyer, A., 1979. Mittäglischer Stomataschluss bei Aprikose (Prunus armeniaca) und Wein (Vitis vinifera) im Freiland trozt guter Bodenwasser-Versorgung. Flora, 168: 511528.

Liu, W.T., Wenkert, W., Allen, L.H. and Lemon, E.R., 1978. Soil-plant water relations in a New York vineyard: resistances to water movement. J. Am. Soc. Hortic. Sci., 103: 226-230.

Loveys, B.R. and Kriedemann, P.E., 1973. Rapid changes in abscissic-like inhibitors following alterations in vine leaf water potential. Physiol. Plant., 28: 476-479.

Ludlow, M.M., 1980. Adaptative significance of stomatal responses to stress. In: N.C. Turner and P.J. Kramer (Editors), Adaptation of Plants to Water and High Temperature Stress. Wiley Interscience, New York, pp. 123-138.

Monteith, J.L., 1965. Evaporation and environment. In: G.E. Fogg (Editor), The State and Movement of Water in Living Organisms. 19th Symp. Soc. Experimental Biol., Academic Press, New York, pp. 205-234.

Rambal, S., 1980. Modélisation de l'utilisation de l'eau et de la production végétale d'une steppe à Rhantherium suaveolens Desf. de la zone aride sud tunisienne. Thèse D.I., USTL, Montpellier, $188 \mathrm{pp}$.

Rambal, S., 1988. From daily transpiration to seasonal water balance: an optimal use of water? In: J. Roy and F. di Castri (Editors), Time Scales of Biological Responses to Water Constraints. The Case of Mediterranean Biota. Springer, Berlin (in press).

Reed, K.L., Hamerly, E.R., Dinger, B.E. and Jarvis, P.G., 1976. An analytical model for field measurement of photosynthesis. J. Appl. Ecol., 13: 925-942.

Rey, $P ., 1957$. Le déterminisme écologique de la répartition des plantes méditerranéennes en Aquitaine. Bull. Soc. Hist. Natl. Toulouse, 92: 131-156.

Riou, C., Pieri, P. and Valancogne, C., 1987. Variation de la vitesse du vent à l'intérieur et audessus d'une vigne. Agric. For. Meteorol., 39: 143-154.

Rives, M., 1975. Les origines de la vigne. Recherche, 6: 120-129.

Schulze, E.D., 1986. Carbon dioxide and water vapor exchange in response to drought in the atmosphere and in the soil. Annu. Rev. Plant Physiol., 37: 247-274.

Schulze, E.D. and Küppers, M., 1979. Short-term and long-term effects of plant water deficits on stomatal response to humidity in Corylus avellana L. Planta, 146: 319-326.

Sheriff, D.W., 1979. Stomatal aperture and the sensing of the environment by guard cells. Plant Cell Environ., 2: 15-22.

Squire, G.R. and Black, C.R., 1981. Stomatal behaviour in the field. In: P.G. Jarvis and T.A. Mansfield (Editors), Stomatal Physiology. Cambridge University Press, London, pp. 223-245.

Stålfelt, M.G., 1962. The effect of temperature on opening of the stomatal cells. Physiol. Plant., 15: 772-779.

Thom, A.S., 1975. Momentum, mass and heat exchange of plant communities. In: J.L. Monteith (Editor), Vegetation and the Atmosphere. Academic Press, London, pp. 57-109.

Thomas, J.C., Brown, K.W. and Jordan, W.R., 1976. Stomatal response to leaf water potential as affected by preconditioning water stress in the field. Agron. J., 68: 706-708.

Turner, N.C., 1986a. Crop water deficits: a decade of progress. Adv. Agron., 39: 1-51.

Turner, N.C., 1986b. Adaptation to water deficits: a changing perspective. Aust. J. Plant Physiol., 13: 175-190.

Van Bavel, C.H.M., Newman, J.E. and Hilgeman, R.H., 1967. Climate and estimated water use by an orange orchard. Agric. Meteorol., 4: 27-37.

Webb, R.A., 1972. Use of the boundary line in the analysis of biological data. J. Hortic. Sci., 47: $309-319$. 
Whitehead, D., Okali, D.U.U. and Fasehun, F.E., 1981. Stomatal response to environmental variables in two tropical forest species during the dry season in Nigeria. J. Appl. Ecol., 18: 571587.

Williams, W.E., 1983. Optimal water-use efficiency in a California shrub. Plant Cell Environ., 6: 145-151.

Winkler, A.J., Cook, J.A., Kliewer, W.M. and Lider, L.A., 1974. General Viticulture. University California Press, Berkeley, CA, 710 pp.

Zeiger, E., 1983. The biology of stomatal guard cells. Annu. Rev. Plant Physiol., 34: 441-475. 